\title{
Implementation and Challenges of the Tsunami Warning System in the Western Mediterranean
}

\author{
F. Schindelé, ${ }^{1}$ A. Gailler, ${ }^{1}$ H. HéBert, ${ }^{1}$ A. Loevenbruck, ${ }^{1}$ E. Gutierrez, ${ }^{1}$ A. Monnier, ${ }^{1}$ P. Roudil, ${ }^{1}$ \\ D. REYMOND, ${ }^{2}$ and L. RiverA ${ }^{3}$
}

\begin{abstract}
The French Tsunami Warning Center (CENALT) has been in operation since 2012. It is contributing to the Northeastern and Mediterranean (NEAM) tsunami warning and mitigation system coordinated by the United Nations Educational, Scientific, and Cultural Organization, and benefits from data exchange with several foreign institutes. This center is supported by the French Government and provides French civil-protection authorities and member states of the NEAM region with relevant messages for assessing potential tsunami risk when an earthquake has occurred in the Western Mediterranean sea or the Northeastern Atlantic Ocean. To achieve its objectives, CENALT has developed a series of innovative techniques based on recent research results in seismology for early tsunami warning, monitoring of sea level variations and detection capability, and effective numerical computation of ongoing tsunamis.
\end{abstract}

\section{Introduction and Objectives}

In the aftermath of both the 26 December 2004 Indian Ocean major tsunami and the 2005 World Conference on Disaster Reduction in Kobe, UNESCO was mandated to coordinate the implementation of tsunami warning systems in all ocean basins affected by tsunamis. The French government supported this decision and participated actively in the UNESCO framework for all ocean basins.

The Western Mediterranean and Northeastern Atlantic are recognized as having been affected by tsunamis. The famous 1755 Lisbon and 1908 Messina earthquakes were both disastrous events; the induced

1 CEA-DAM Île de France, Arpajon, France. E-mail: francois.schindele@cea.fr

2 Laboratoire de Géophysique de Pamatai, CEA, DAM, DASE, Papeete, French Polynesia.

3 Ecole et Observatoire des Sciences de la Terre, Strasbourg, France. tsunamis devastated the closest coastlines, where more than 10,000 tsunami victims were reported in each case. More recently, the magnitude 6.9 Boumerdes Algerian earthquake in 2003 generated a tsunami which affected the Balearic Islands half an hour later with waves higher than $2 \mathrm{~m}$ (AlASSET et al. 2006). The waves affected several harbors, where 200 boats sunk or were damaged, and several coastal zones and restaurants were inundated. One hour later, on the French Riviera coast, a 1.5-m rapid draw-down was observed with strong currents and eddies in at least eight harbors (SAHAL et al. 2009). Several small boats sunk or were damaged. Fortunately, this tsunami occurred in May, at night, when very few people were in the harbors or beaches. The same event in August would have been more disastrous because of the presence of hundreds of thousands of people on beaches and in harbors. A larger magnitude earthquake occurring in summer is indeed the worst-case tsunami in the Mediterranean.

As a consequence of the 2003 tsunami, and as initiated in the aftermath of the 2004 Indian Ocean tsunami, the UNESCO Intergovernmental Coordination Group (ICG) of the Northeastern Atlantic, Mediterranean, and connected seas tsunami warning and mitigation system adopted a specific "decision matrix" for the Mediterranean Sea. This decision matrix is an operating procedure that automatically defines the level of alert and the type of message (Information, Advisory, Watch), taking into account several geographical and seismological factors: the location of the epicenter, offshore or inland within a distance to the coastline, the focal depth, the magnitude, and the epicentral distance to any point of interest (Tables 1, 2).

The CENALT (Centre d'alerte aux tsunamis, RoudiL et al. 2013) was created within the scope of 
Table 1

Decision matrix in the Mediterranean region

\begin{tabular}{|c|c|c|c|c|}
\hline Depth & Location & Mw & $\begin{array}{l}\text { Distance to the } \\
\text { epicenter }\end{array}$ & Type of message \\
\hline \multirow{10}{*}{$<100 \mathrm{~km}$} & \multirow{6}{*}{ Offshore or inland ( $\leq 40 \mathrm{~km}$ inland) } & {$[5.5 ; 6.0]$} & Everywhere & Information Bulletin \\
\hline & & \multirow{2}{*}[6.0;6.5]{} & $\leq 400 \mathrm{~km}$ & Tsunami Advisory \\
\hline & & & $>400 \mathrm{~km}$ & Information Bulletin \\
\hline & & \multirow{2}{*}[6.5;7.0]{} & $\leq 400 \mathrm{~km}$ & Tsunami Watch \\
\hline & & & $>400 \mathrm{~km}$ & Tsunami Advisory \\
\hline & & $\geq 7.0$ & Everywhere & Tsunami Watch \\
\hline & \multirow{4}{*}{ Inland $(>40 \mathrm{~km}$ and $\leq 100 \mathrm{~km}$ inland) } & {$[5.5 ; 6.5]$} & Everywhere & Information Bulletin \\
\hline & & \multirow{2}{*}[6.5;7.0]{} & $\leq 400 \mathrm{~km}$ & Tsunami Watch \\
\hline & & & $>400 \mathrm{~km}$ & Tsunami Advisory \\
\hline & & $\geq 7.0$ & Everywhere & Tsunami Watch \\
\hline$\geq 100 \mathrm{~km}$ & Offshore or inland $(\leq 100 \mathrm{~km})$ & $\geq 5.5$ & Everywhere & Information Bulletin \\
\hline
\end{tabular}

Table 2

Decision matrix in the Northeastern Atlantic region

\begin{tabular}{|c|c|c|c|c|}
\hline Depth & Location & $M w$ & $\begin{array}{l}\text { Distance to the } \\
\text { epicenter }\end{array}$ & Type of Message \\
\hline \multirow{6}{*}{$<100 \mathrm{~km}$} & \multirow{6}{*}{ Offshore or inland ( $\leq 100 \mathrm{~km}$ inland) } & {$[5.5 ; 7.0]$} & Everywhere & Information Bulletin \\
\hline & & \multirow[t]{2}{*}[7.0;7.5]{} & $\leq 1000 \mathrm{~km}$ & Tsunami Advisory \\
\hline & & & $>1000 \mathrm{~km}$ & Information Bulletin \\
\hline & & \multirow{2}{*}[7.5;7.9]{} & $\leq 1000 \mathrm{~km}$ & Tsunami Watch \\
\hline & & & $>1000 \mathrm{~km}$ & Tsunami Advisory \\
\hline & & $\geq 7.9$ & Everywhere & Tsunami Watch \\
\hline$\geq 100 \mathrm{~km}$ & Offshore or inland $(\leq 100 \mathrm{~km})$ & $\geq 5.5$ & Everywhere & Information Bulletin \\
\hline
\end{tabular}

the UNESCO framework. At the ICG meetings in Lisbon (2007) and Athens (2008) France undertook to develop a national tsunami warning center for the Northeastern Atlantic and Mediterranean and to offer international coverage of the Western Mediterranean.

In this paper we describe the development of the CENALT warning system since 2009, including the development of specific techniques to ensure service efficiency, for example tsunami travel time and height computation, methodology to enhance sea level-monitoring networks, and techniques to assist in the rapid determination of seismological data.

\subsection{Building the Tsunami Warning System}

The operational parts of the tsunami warning systems currently implemented in other basins are composed of three main components: a real-time seismological network for earthquake detection and characterization, a real-time sea-level network (tide gages and tsunameters) for tsunami confirmation and measurement, and tsunami warning centers for data processing and message dissemination. In the Pacific, two national tsunami warning centers (PTWC USA, and JMA Japan) are providing alert 
messages to national tsunami warning centers and tsunami warning focal points (Intergovernmental Oceanographic Commission 2013) with decision matrixes, hence using criteria based on location of the epicenter (offshore, inland) and on two seismic variables, magnitude and focal depth. In the Indian Ocean, after the interim phase 2005-2012 covered by PTWC and JMA with the same criteria as in the Pacific, three centers, Australia, India, and Indonesia, are providing alert and forecast products. They are also based on seismic and tide-gage networks, and use, in addition, scenario databases resulting from modeling, and techniques enabling estimation of tsunami height on the shoreline. The criteria implemented in the Northeastern Atlantic and Mediterranean region will be described later in that section.

With the partnership of the French Hydrographic and Oceanographic Service (SHOM) and the National Institute for Earth Sciences and Astronomy of the National Center of Scientific Research (CNRS-INSU), the Commissariat à l'énergie atomique et aux énergies alternatives (CEA) was charged in 2009 by French authorities with the creation and operation of a tsunami warning system and center by 2012 .

CEA's mandate was to build a system which can:

1. detect a potentially tsunamigenic earthquake;

2. compute and evaluate earthquake and tsunami data; and

3. inform French civil protection authorities and countries of the Euro-Mediterranean region, using criteria adopted by the ICG.

CEA faced several challenges in implementing CENALT components. The first was related to the small size of Western Mediterranean, which is crossed by a tsunami in about 60 min. This time frame requires a warning center which can react very quickly (SCHINDELÉ et al. 2008). The second was related to the requirement to characterize the effect of a tsunami during the event. In addition, the networks should be monitored to guaranty the continuity of the service and to continuously assess the capacities for detection of earthquake and tsunami.

To meet these challenges, CENALT operates 24/7 with the objective of disseminating to French authorities a watch or advisory message less than 15 min after the event.

The warning center has the following objectives:

- To transmit an alert to the French authorities within $15 \mathrm{~min}$ of a potentially tsunamigenic earthquake occurring in the Western Mediterranean or Northeastern Atlantic, and to transmit a message within the same time period to international warning centers and tsunami focal points in the Euro-Mediterranean region. Both messages contain earthquake data and, when relevant, expected tsunami arrival time and alert level.

- To transmit supplementary messages confirming (or ruling out) the occurrence of a tsunami which will also provide the real arrival time and amplitude measured on tide-gage records. The time the supplemental message is issued will depend on the availability of tide-gage data.

\subsection{Threat Evaluation: Decision Matrix and Tsunami Arrival Time}

CENALT receives data via satellite and private telecommunication networks from:

- seismic stations used to record seismic waves which are processed to compute an earthquake's epicenter, magnitude, and other seismic data (Fig. 1); and

- sea-level stations (tide gages) used to record tsunamis (Fig. 1).

A primary seismic network of high-quality, reliable stations has been identified. This primary network includes the CEA and CNRS-INSU stations, which are complemented by neighboring countries' networks: Instituto Portuguès do Mar e da Atmosfera (Portugal), Instituto Geografico Nacional (Spain), Istituto Nazionale di Geofisica e Vulcanologia (Italy), Real Observatorio de la Armada and Universidad Complutense de Madrid (Spain), Institut national de météorologie (Tunisia), and GeoForschungsZentrum (Germany).

The ICG defined three alert levels (UNESCO 2012) to provide relevant tsunami threat information to civil protection agencies: 


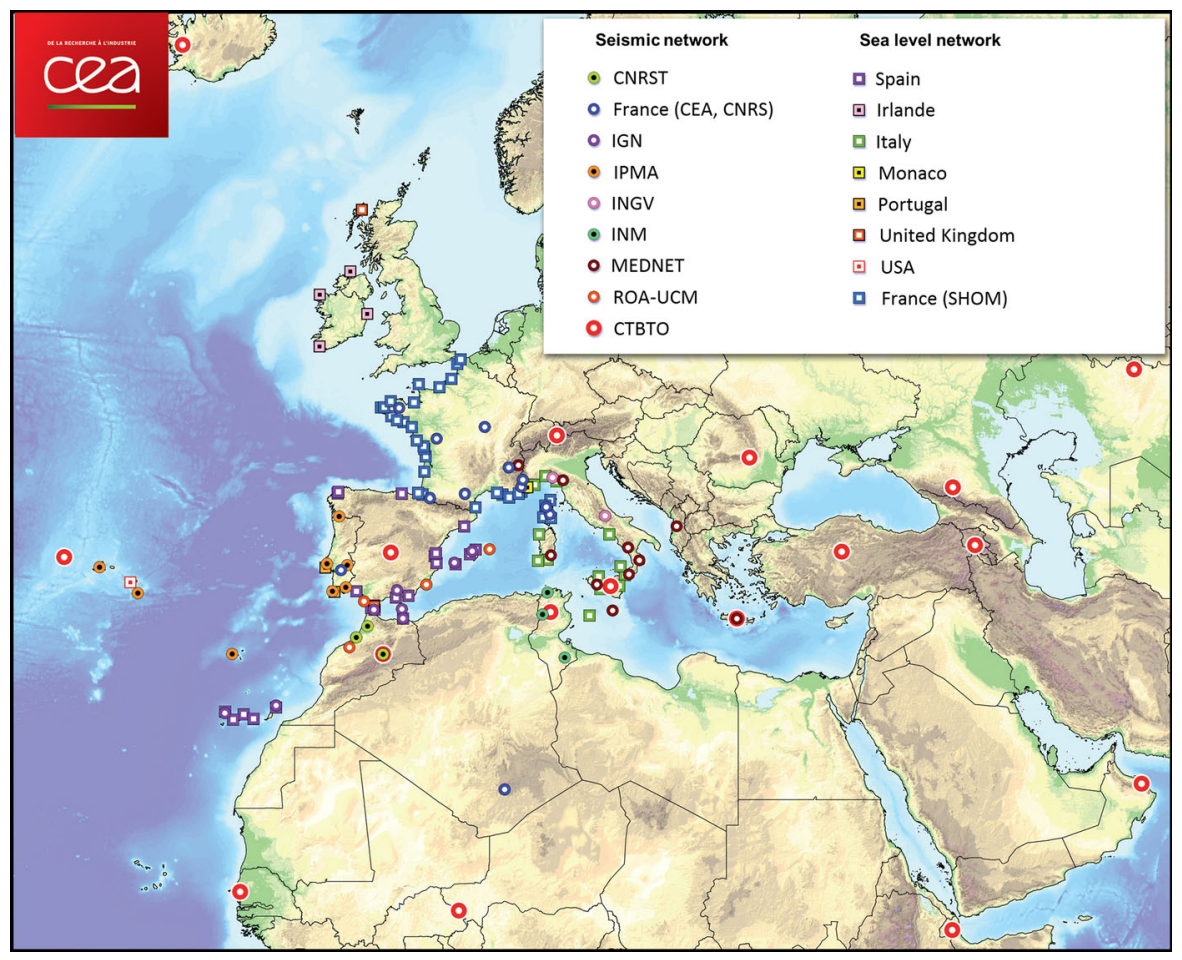

Figure 1

Map of the CENALT seismic and sea level network

- Information: no tsunami threat;

- Advisory: potential impact in harbors, estuaries and along beaches (marine threat); and

- Watch: possible inundation is expected in several zones along the coastline.

These three alert levels are constrained by the decision matrix, thus by geographical and geophysical data, as shown in Table 1. Earthquake magnitude, focal depth, distance from shoreline, and distance to forecast points define the response. Tsunami forecast points are the locations defined by Member States for which the Tsunami Warning Center, or other organization, provides an estimate of tsunami arrival time and/or wave height. They may correspond to important, vulnerable coastal cities or populated areas, and/or to the locations of sea-level gages.

The methodology and criteria used to define the magnitude threshold are the same as implemented in the Pacific region since the 1990s and in the Caribbean region since 2006. The threshold values in the Northeastern Atlantic are similar to those in the
Pacific Ocean (Table 2), although addition of a marine threat (advisory alert level) is different from the Pacific or Caribbean.

This is because the Western Mediterranean has been affected by tsunamis generated by a relatively small earthquake, for example that in 2003 (magnitude 6.9), described above. This earthquake's dip angle value was much larger $\left(35^{\circ}-45^{\circ}\right)$ than the average subduction zone dip angle $\left(6^{\circ}-15^{\circ}\right)$ which may explain why it generated a larger tsunami than expected on the basis of magnitude alone.

Another factor to consider when devising criteria for the Mediterranean is the small size of Mediterranean sub-basins (Western, Adriatic, and Eastern). These basins are crossed by tsunamis in less than 60-80 min. Islands are also located frequently within a half an hour tsunami travel time from the seismic zone, and in the maximum direction of tsunami energy propagation. Several studies have been performed which demonstrate the need to modify the magnitude criteria in the Western Mediterranean basin (Alasset et al. 2006; SAHAl et al. 2009; Roger et al. 2011). For the advisory level, the magnitude 
threshold is 6.0 for the regional scale $(<400 \mathrm{~km})$ and 6.5 for the basin scale $(>400 \mathrm{~km})$. For the watch level, the magnitude threshold is 6.5 for the regional scale and 7.0 for the basin scale (UNESCO 2012).

In each basin and for each tsunami warning system, it is acknowledged that the first necessary information for the alert process is the tsunami arrival time. When an earthquake is identified as potentially tsunamigenic, tsunami travel times are computed automatically considering only the location of the epicenter and the bathymetry. The code TTT (Tsunami Travel Times, Geoware ${ }^{\circledR}$ ) computes the tsunami travel time by use of Huygen's principle; that is, all wave front points are considered source points for secondary spherical waves (SнокіN et al. 1987). The forecast time of arrival of the first tsunami is computed for all forecast points by adding the travel time to the origin time of the earthquake. These forecast arrival times are included in the alert messages.

Because forecasted tsunami arrival times must be issued within 15 min of the earthquake origin (see paragraph above on operation objectives), the seismic source is initially regarded as a point source. Such arrival times are always approximate, but are very important for the alert. It should also be noted that tsunami arrival times are for initial arrival of the tsunami and do not correspond to the time of the maximum waves which may arrive later.

\subsection{Assessment and Improvement of Sea Level Detection Capacity}

SHOM provides continuous real time data from 34 sea-level stations directly to the CENALT. Data from neighboring countries are supplied through the Intergovernmental Oceanographic Commission (IOC) web page (http://www.ioc-sealevelmonitoring.org/) where the data are available with a five to, sometimes, more than 30 min delay. It should be noted that only SHOM is providing data through the Global Telecommunication System (GTS) with a latency of $6 \mathrm{~min}$. This system will be upgraded in the coming years to a latency of only 1-2 min which is optimum for fast tsunami detection.

To rapidly confirm tsunami generation soon after the first message, a minimum delay of the sea level data recorded at the center is absolutely necessary. A priori knowledge of tsunami detection delay is an important aspect of a warning system: CENALT is the first center to implement such a tool. The method is based on the fact that the detection delay can be computed theoretically from travel times to all the tide gages in operation.

CEA developed a specific tool that monitors the sea level network and its detection capacity. It reports the network performance continuously and whether each tide gage is operating optimally, delayed or with short data gaps, or is out of order. The outputs of each tide gage are the transmission latency and the percentage of data gaps.

For each tide gage, the detection delays are assessed by taking into account the reversibility of the tsunami travel time computed from a tide gage to the source and from the source to the tide gage. The detection delays for each specific tide gage are computed considering the tsunami travel times for each grid cell of the sea or ocean basin, and adding the transmission data delay plus a time for tsunami measurement. This last value takes into account that at least a quarter of the wave period, typically about $6 \mathrm{~min}$, is necessary before analysis (SCHINDELÉ et al. 2008).

Detection delays within a basin or sub-basin are computed by combining the contributions of each tide gage. The tool considers that the tsunami waves must be detected by one tide gage only. Figure 2 shows the map computed for the current network implemented in the Western Mediterranean sea. This map reflects the heterogeneity of the network, with a minimum delay of 15-20 min for the best covered zones (Ligurian sea, Corsica, Sicily, and Alboran sea). By contrast, the North Algerian margin is a potential source of generation of tsunamis that would be detected in 50-80 min. For example, the tsunami induced by the Boumerdes earthquake in 2003 would not be confirmed by the current tide-gage network in less than $70 \mathrm{~min}$, and the travel time to the mostaffected zones was 30-40 min.

To confirm an alert or to cancel it as soon as possible, the French authorities requested CENALT to designate where new tide-gage stations should be located on Western Mediterranean European coastlines to substantially improve tsunami detection. The 


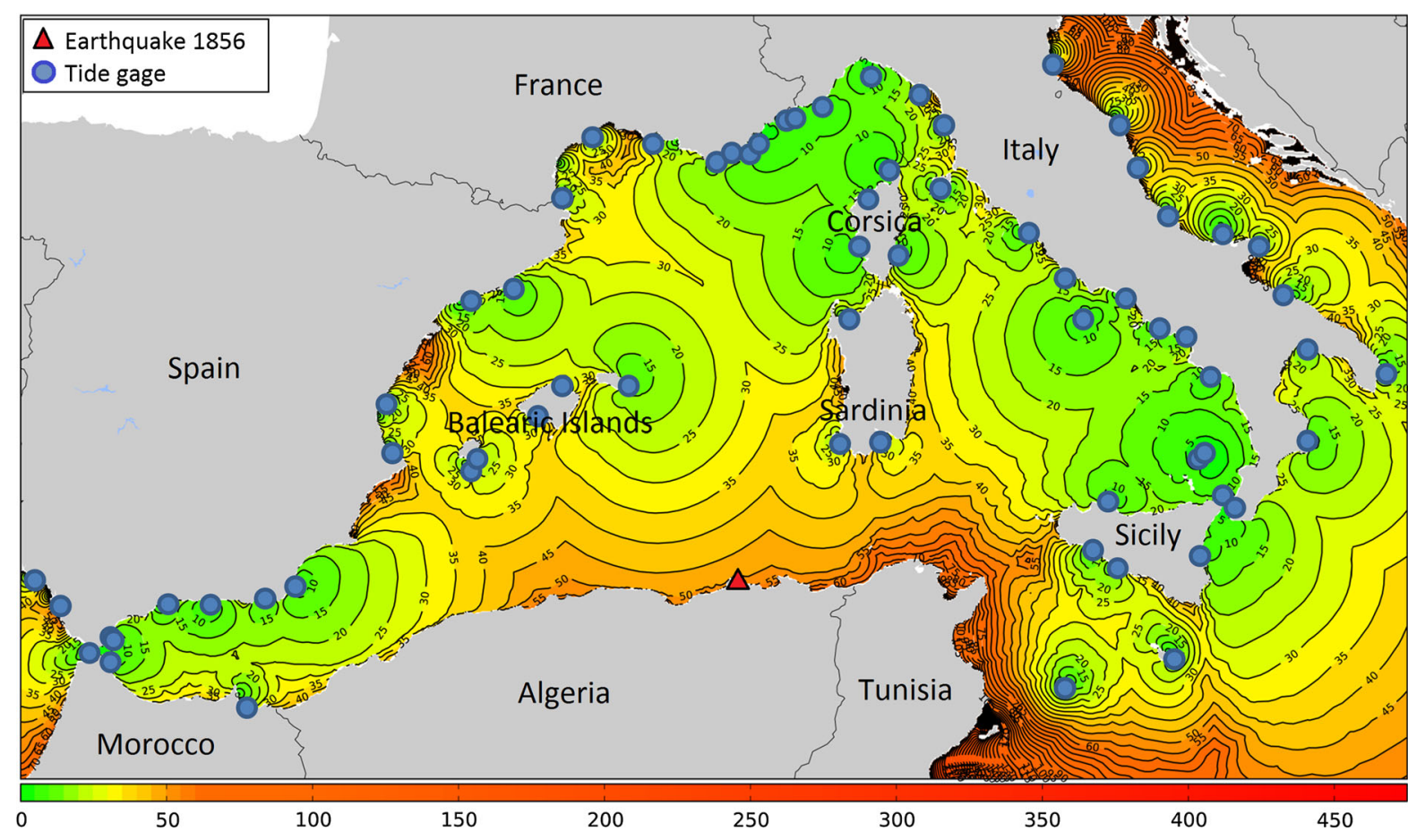

Figure 2

Detection delay map ( $\mathrm{min})$ of Western Mediterranean basin when the complete network is operating. The red triangle is the epicenter of the Djidjelli earthquake, Algeria, in $1856\left(M_{\mathrm{w}}=7,0\right)$; with the current sea-level network this tsunami would be confirmed no earlier than 65 min after the earthquake

priority was given to the source region from Western Algeria to Northern Tunisia. The closest European coastlines are the Balearic Islands (Ibiza, Formentera, Majorca, Cabrera, and Minorca), Sardinia, and Sicily.

To determine optimum tide-gage locations, fourstep methodology was developed:

1. search sites and coordinates of the harbors/ports/ marinas of these seven islands for potential tide gage locations;

2. compute the travel time for each of the proposed tide gages to a set of forecast points (13 forecast points located every $75 \mathrm{~km}$ along the coastline of Algeria);

3. for each of the proposed tide gages, compute the difference between the travel time for the current network and the travel time including this tide gage in the set of forecast points; and

4. determine which proposed tide gages best reduce tsunami detection latency.

Forty-seven potential harbors on the seven islands were tested using this methodology: Formentera (1), Ibiza (2), Cabrera (2), Majorca (3), Minorca (2),
Sardinia (18), and Sicily (19). The results are summarized in Fig. 3. Eighteen stations improve tsunami detection by less than $10 \mathrm{~min}$ (cumulative for all forecast points); 21 stations improved detection by $10-40 \mathrm{~min}$; and eight stations improved detection by more than $40 \mathrm{~min}$.

Figure 4 shows that tsunami detection can be improved for the Algerian coast by using only seven of these eight stations. To ensure the sustainability of such a detection network, the operation and maintenance cost of the new tide gages must be minimized as much as possible. Considering both costs and that tsunami detection reductions of less than 5 min are not essential, further analysis of Fig. 4 indicates that only four of the best seven locations are necessary to substantially improve tsunami detection: one on Formentera island, one in Cabrera or on Southern Majorca, one in Sardinia, and one in Sicily. The difference between detection times using four stations only and using seven is less than 2 min for $95 \%$ of the Algerian coastline (Fig. 4). From point 11 to point 12 , only, the difference varies from 2 to $5 \mathrm{~min}$. 


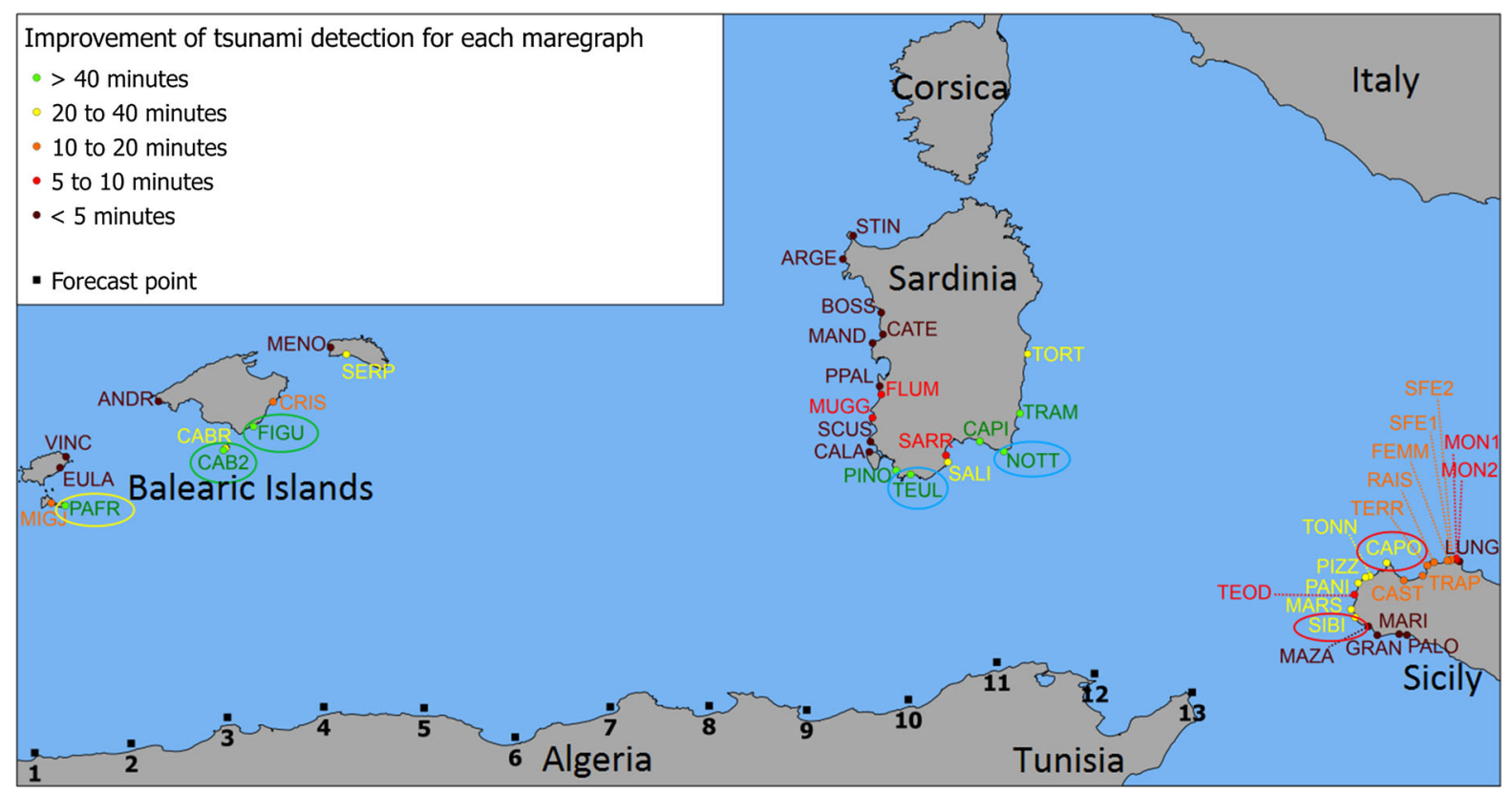

Figure 3

Western Mediterranean map with proposed tide-gage sites (in harbors/ports) and forecast points on the north African coast (the seven circled tide gages are those that improved tsunami detection the most)

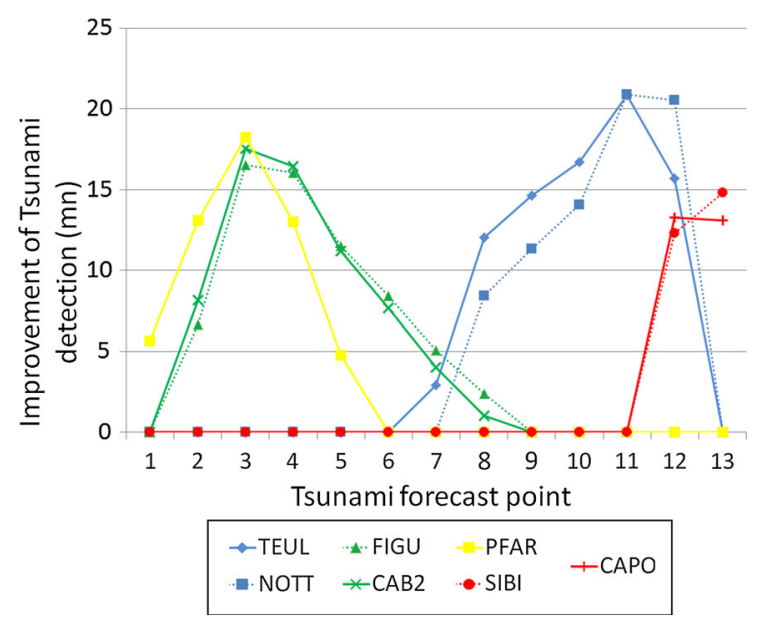

Figure 4

Detection delay reduction (min) for the 13 forecast points by using the seven best tide-gage stations (one on Formentera Island $(P F A R)$, Cabrera Island (CAB2), Southern Majorca (FIGU),

Sardinia (TEUL and NOTT), and Sicily (SIBI and CAPO)

Nevertheless, for the North Algerian source region, detection delays as a result of adding these four tide gages would vary from 35 to $45 \mathrm{~min}$ (Fig. 5a, b).
Such a study should be performed for all coastlines to guide the implementation of new tide-gage stations that could improve the network detection capability.

Another conclusion from this analysis is related to the implementation of tsunameters in the future. The study demonstrates that between forecast points 5 and 8 tsunami detection could not be reduced substantially with coastal stations implemented on European island coastlines. We recommend implementing tsunameters in the deep sea offshore along the region from forecast points 5-8. These two tsunameters should be located $50-55 \mathrm{~km}$ to the north of point 5 and point 8 . The detection delay of tsunami waves from point 3 to point 10 would then be less than 15-25 min after earthquake occurrence.

\subsection{Alert Level Refinement: Pre-computed Scenario Data Bases}

When a tsunami alert occurs, CENALT should specify, in less than $2 \mathrm{~h}$, to the COGIC (Centre opérationnel de gestion interministérielle des crises; the French center for Interministerial crisis 

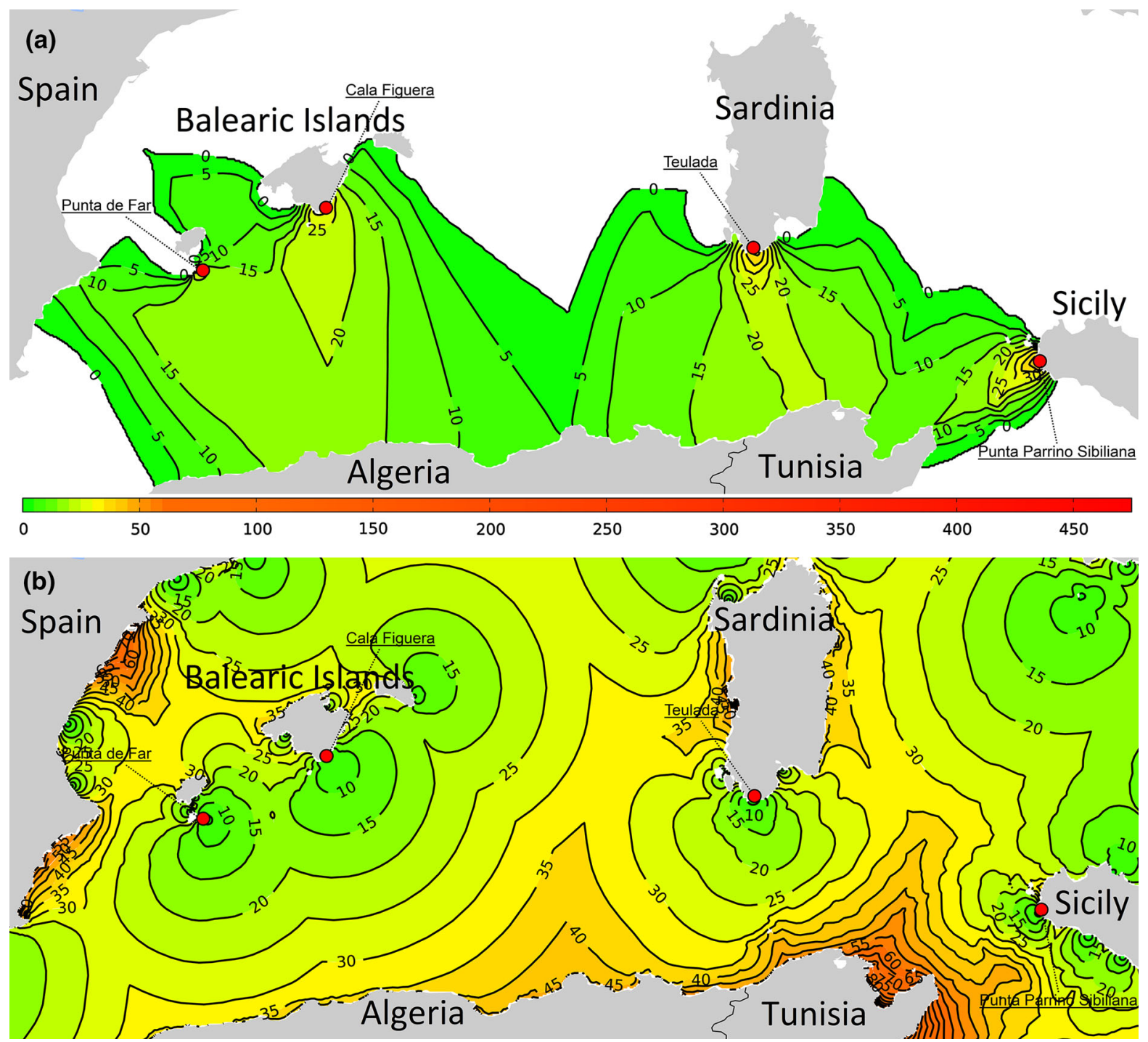

Figure 5

Detection delay reduction by addition of four tide gages: a detection delay reduction ( $\min$ ), b detection delay map (min) considering the contribution of the four best stations (Pfar, Figu, Teul and Sibi)

management), the location of the most threatened regions. This information is obtained at CENALT by an automatic tsunami modeling tool which uses a precomputed scenario data base. This tool provides, in addition to the tsunami arrival time map, other relevant maps which take into account uncertainties in source location and magnitude (GAILLER et al. 2013).

When a potentially tsunamigenic earthquake occurs, three different maps are provided which combine several pre-computed cases to obtain composite scenarios representing the earthquake. These maps (Fig. 7) show the tsunami height offshore for the most probable scenario, the minimum scenario, and the maximum scenario based on uncertainties in location and magnitude. In addition to the alert-level map computed in the first minutes after the earthquake using the decision matrix (UNESCO 2012), these three additional maps provide information concerning the source directivity; that is, the main tsunami energy axes and which areas are the main zones at risk. The methodology used to determine these tsunami impact maps is based on: 
- implementation of a pre-computed unit source function data base;

- the unit sources aggregation method chosen to obtain a composite scenario, according to the magnitude of a detected earthquake; and

- consideration of uncertainty in the earthquake data.

The pre-computed tsunami propagation unit scenario data base is modeled on a well-known seismo-tectonic context. Because this context is rather complex along the North African margin, the choice was made to draw a simplified fault system discretized into unit sources corresponding to the major structural trends of the area. The unit source database used a comprehensive bibliography including seismicity catalogs, focal mechanisms, seismotectonic works (e.g., Pondrelli et al. 2004; Álvarez Gómez et al. 2011), seismic reflection profiles (e.g., DÉVERChÈre et al. 2005), bathy/topo data, satellite imagery, etc., to propose an exhaustive geodynamic framework (extending beyond works such as LoRito et al. 2008 or SORENSEN et al. 2012). Fault traces shown on Fig. 6 represent the up-dip edge of the unit sources. The length $(L)$ and width $(W)$ of each unit source are set at $25 \mathrm{~km}$ and $20 \mathrm{~km}$, respectively. Values of $L$ and $W$ are defined from empirical relationships linking $L$ and $W$ to the magnitude $M_{\mathrm{w}}$ (Wells and COPPERSMITH 1994).

For each unit source, tsunami propagation modeling was performed using the CEA simulation code solving the hydrodynamic equations under the nonlinear shallow water assumption (Heinrich et al. 1998; HÉBERT et al. 2001, 2007), with a 2 ' bathymetric grid increment, a $1 \mathrm{~m}$ slip of the rupture, and with regionalized dip, rake, and strike angle values based on local seismotectonic history. Every computed scenario archived in the data base represents a tsunami induced by a hypothetical $M_{\mathrm{w}} 6.76$ earthquake and propagates the tsunami for $3 \mathrm{~h}$ in the Western Mediterranean.

The number of pre-computed tsunami scenarios used in the real-time computation depends on the magnitude of the composite solution. Every composite estimate matches a linear combination of $x$ single pre-computed scenarios $(x=1-2 \times 8)$, multiplied by an appropriate scale factor $F_{\mathrm{s}}$. The methodology used to compute $F_{\mathrm{s}}$ was inspired by GREENSLADE $e t \mathrm{al}$. (2009). Composite wave heights, $H_{\text {comp, from an }}$ event with seismic moment $M_{\mathrm{o}(\mathrm{comp})}=F_{\mathrm{s}} M_{\mathrm{o}}$ can be generated with the same rupture length and width with a modified slip $u_{\mathrm{o}(\mathrm{comp})}=F_{\mathrm{s}} u_{\mathrm{o}}$ (Gailler et al. 2013). From the linearity of the physics of tsunami generation and propagation in the ocean, $H_{\text {comp }}=F_{\mathrm{s}} H$. The appropriate value of $F_{\mathrm{s}}$ is derived from the well-known relationship between the magnitude and seismic moment: $F_{\mathrm{S}}=10^{3 / 2\left(M_{\mathrm{w}(\mathrm{comp})}-M_{\mathrm{w}}\right)}$.

To take into account errors in the initial earthquake processing, composite scenario computation takes into account uncertainties in the epicenter location (single source selected in a $20 \mathrm{~km}$ radius circle), and the magnitude uncertainty $( \pm 0.2)$.

Figure 7 shows the results of the methodology applied to the 1856 Djidjelli earthquake and tsunami (Roger and Hébert 2008; Yelles-Chaouche et al. 2009). Figure $7 \mathrm{~b}$ is computed for magnitude 6.9 $\left(F_{\mathrm{s}}=1.61,1\right.$ unit source), Fig. 7c uses magnitude $6.7\left(F_{\mathrm{s}}=0.81,1\right.$ unit source $)$, and Fig. $7 \mathrm{~d}$ uses magnitude $7.1\left(F_{\mathrm{s}}=1.61,2\right.$ unit sources $)$.

\subsection{Rapid Assessment of Tsunami Threat}

Real earthquakes sometimes have properties very different from those of the identified generic sources used for pre-computed scenarios. Indeed, the type of rupture (reverse, normal, or strike-slip) has a major effect on the seafloor deformation. In particular, a strike slip earthquake mechanism would induce a tsunami about a factor of 10 smaller than a reverse fault earthquake with the same magnitude. During the last 20 years, significant effort has been devoted to the development of methods for rapid characterization of the seismic source mechanism.

\subsubsection{CENALT is Implementing and Testing Two Different New Tools}

The first method is determination of the W-Phase centroïd moment tensor (KANAMORI and RiverA 2008). The $\mathrm{W}$-phase can be interpreted as superposition of the fundamental mode, and the first, second, and third overtones of spheroidal modes at long period. The group velocity of $\mathrm{W}$ phase ranges from 


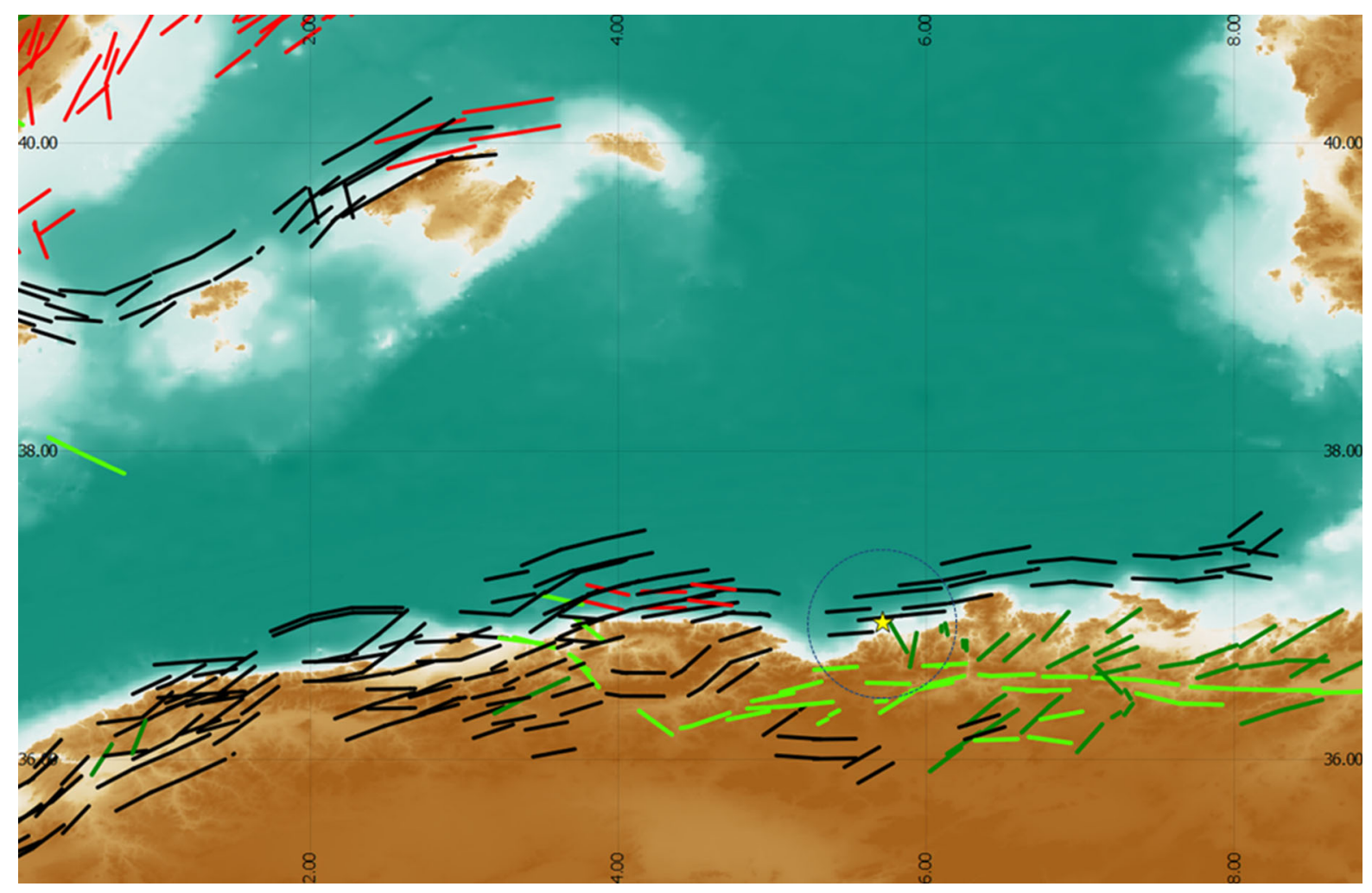

Figure 6

Detailed view of the 1856 Djidjelli earthquake and pre-computed unit source scenarios available in the area. Each colored segment represents the top edge of a $25 \times 20 \mathrm{~km}$ unit source scenario stored in the pre-computed database: black, thrust faults; red, normal faults; light green, dextral strike-slip faults; green, sinistral strike-slip faults; yellow star, epicenter of the event; and blue dashed circle, source inaccuracy radius

4.5 to $9 \mathrm{~km} \mathrm{~s}^{-1}$ over a period range from 100 to $1000 \mathrm{~s}$. The propagation of $\mathrm{W}$ phases is not strongly affected by the strong shallow structural heterogeneities caused by the subduction zones, the continents, and the oceans. The $\mathrm{W}$-Phase inversion code has recently been developed (2008-2012) to rapidly obtain source inversion results for major and megaearthquakes, and in particular for the non-typical events referred to as "tsunami earthquakes". Large earthquakes are particularly difficult to characterize, and each consists of a specific case. Because of the fast group velocity of the $\mathrm{W}$-phase, most of the $\mathrm{W}$-phase energy is contained within a short time window after arrival of the P-wave (Fig. 8). The principal interest of this method is its rapidity and robustness for seismic moment evaluation.

The second method was developed at the Centre Polynésien de Prévention des Tsunamis (CPPTTahiti), and implemented by CEA. This new method called PDFM2 (Preliminary Determination of Focal Mechanism 2) which is fully integrated for real-time analysis, gives robust and accurate earthquake source data (focal mechanism and seismic moment) from surface waves spectral modulus and $\mathrm{P}$ wave first motion information in less than $45 \mathrm{~min}$ after the earthquake origin time (REYMOND and CLÉMENT 2014). In addition, the PDFM2 method identifies "tsunami earthquakes" (earthquakes that cause much bigger tsunamis than their magnitude would imply) by using an estimate of the slowness of the seismic event.

Results obtained by use of these methods will be compared in the context of the Mediterranean sea, with frequent large magnitudes varying from magnitude 5.5-7.0, to determine which is the most accurate, robust, and fastest which will provide a rapid tsunami effect forecast. Earthquake data obtained by use of these two techniques are automatically input to the tsunami modeling code in the CENALT multiprocessor 


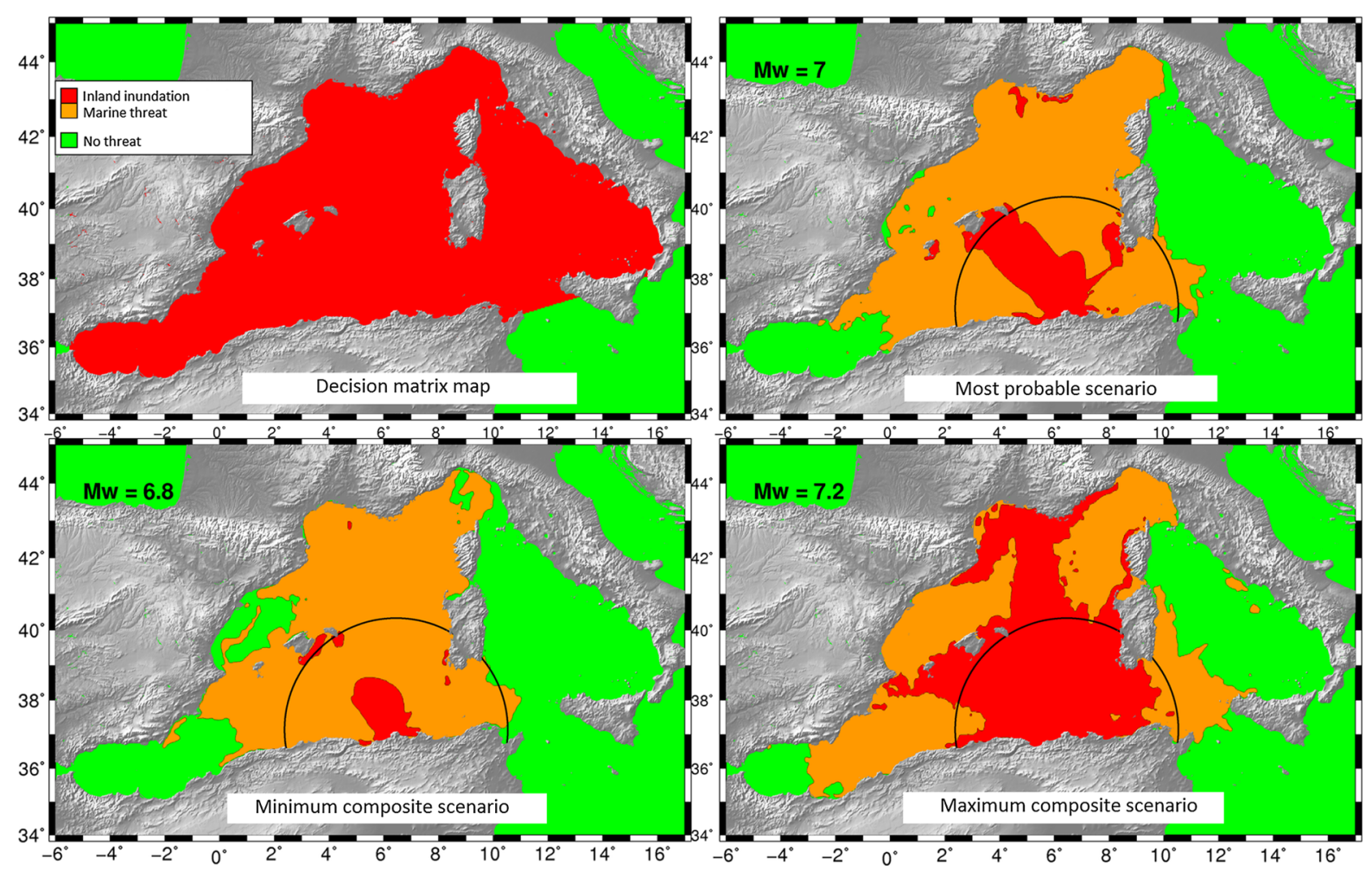

Figure 7

Decision matrix and aggregation maps. Final representation produced by the forecasting system to be delivered to the authorities approximately two hours after detection of a tsunamigenic earthquake. Red zones, area in watch level; black circle, $400 \mathrm{~km}$ radius warning area around the epicenter; orange zones, area in advisory level; green zones, area not expected to be affected by the tsunami waves. East Algeria case (1856-like, $M_{\mathrm{w}}=7.0$ ). a Decision matrix map, $\mathbf{b}$ most probable composite scenario, $\mathbf{c}$ minimum composite scenario, $\mathbf{d}$ maximum composite scenario; $\mathrm{b}, \mathrm{c}$, and $\mathrm{d}$ are calculated by use of composite data base scenarios taking into account the uncertainties of the location of the epicenter and of the magnitude. Advisory (orange) and Watch (red) levels correspond to the levels referred to in the decision matrix

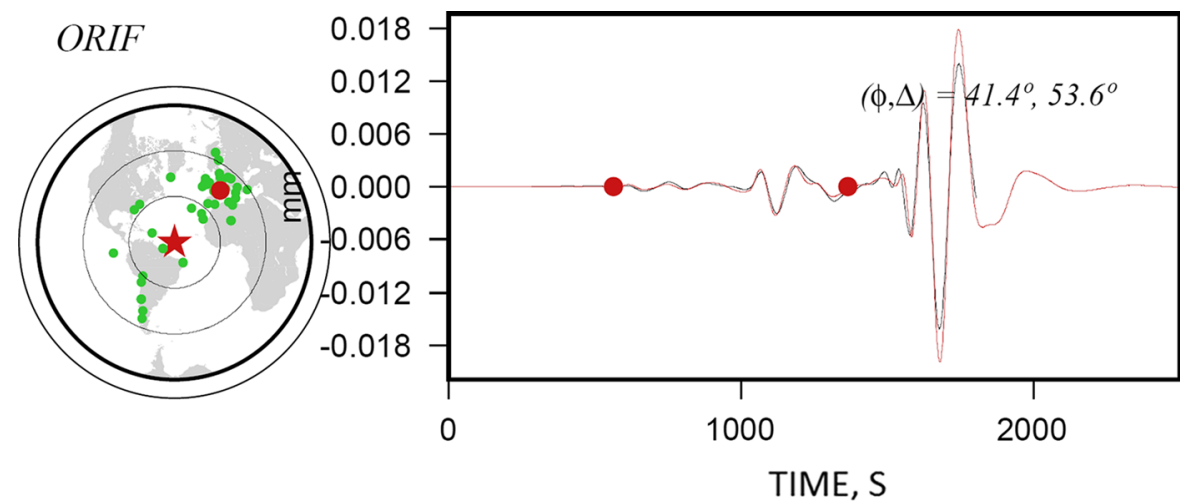

Figure 8

Vertical component record of ORIF seismic station, Northern Atlantic ridge earthquake $\left(M_{\mathrm{w}}=6.7\right)$. The black curve shows the record; the red curve is the computed W-phase (between the two red dots) followed by the surface waves

computers. This code estimates the tsunami amplitude offshore, but in the future the tsunami amplitude on the coastline should also be provided for coastal sites by use of either empirical amplification laws or high-performance simulation when high-resolution bathymetric data are available. 


\section{Conclusion}

Since implementation of the French Tsunami Warning Center, CENALT, several methods have been developed and implemented for rapid earthquake characterization, evaluation of tsunami potential, and tsunami impact characterization. For that purpose, CENALT relies on a network of French seismic stations (CEA, SHOM, CNRS) complemented by additional stations from neighboring countries; the level of detectability of these networks and of operational sea level networks is continuously scrutinized. One of the innovative tools developed provides guidance for the implementation of additional tide-gage stations. A specific study demonstrates that adding four tide gages, two in the Balearic Islands, one in Sardinia, and one in Sicily, would reduce tsunami detection time by more than $20 \mathrm{~min}$ for sources along the North Algeria and Tunisia shoreline.

\section{Acknowledgments}

The authors wish to thank two anonymous reviewers for their very useful and constructive reviews. The CENALT was implemented thanks to the support of the French Ministries of Interior and Ecology, and the work was also recently supported by the FP7 ASTARTE-Assessment, STrategy And Risk Reduction for Tsunamis in Europe. Grant 603839, 7th FP (ENV.2013.6.4-3 ENV.2013.6.4-3).

Open Access This article is distributed under the terms of the Creative Commons Attribution License which permits any use, distribution, and reproduction in any medium, provided the original author(s) and the source are credited.

\section{REFERENCES}

Alasset, P.-J., Hébert, H., Maouche, S., Calbini, V., and MegHRAOUI, M. (2006). The tsunami induced by the 2003 Zemmouri earthquake $\left(M_{\mathrm{w}}=6.9\right.$, Algeria): modelling and results, Geophys. J. Int., 166: 213-226.

Álvarez Gómez, J. A., Aniel-Quiroga, í̃igo, González, M., OlaBARRIETA, M., and CARREÑo, E. (2011). Scenarios for earthquakegenerated tsunamis on a complex tectonic area of diffuse deformation and low velocity: The Alboran Sea, Western Mediterranean, Mar. Geol., 284: 55-73.
Déverchère, J., Yelles, K., Domzig, A., Mercier de Lépinay, B., Bouillin, J.-P., Gaullier, V., Bracène, R., Calais, E., Savoye, B., Kherroubi, A., Le Roy, P., Pauc, H., and Dan, G. (2005). Active thrust faulting offshore Boumerdes, Algeria, and its relations to the 2003 Mw 6. 9 earthquake, Geophys. Res. Lett., 32, L04311.

Gailler, A., Hébert, H., Loevenbruck, A., Hernandez, B. (2013). Simulation systems for tsunami wave propagation forecasting within the French tsunami warning center, Nat. Hazards Earth Syst. Sci., 13: 2465-2482.

Greenslade, D. J.M., Simanjuntak, M. A., and Stewart, C. R. A. (2009). An enhanced tsunami scenario database: T2, Center for Australian Weather and Climate Research (CAWCR), in CAWCR Technical Report, 14.

Hébert, H., Heinrich, P., Schindelé, F., and Piatanesi, A. (2001). Far-field simulation of tsunami propagation in the Pacific Ocean: Impact on the Marquesas Islands (French Polynesia), J. Geophys. Res. 106, C5, 9161-9177.

Hébert, H., Sladen, A., and Schindelé, F.(2007). Numerical modeling of the Great 2004 Indian Ocean Tsunami focus on the Mascarene Islands, Bull. Seismol. Soc. Am. 97, 1A, 208-222.

Heinrich, P., Schindelé, F., Guibourg, S., and Ihmlé, P. (1998). Modeling of the February 1996 Peruvian tsunami, Geophys. Res. Lett., 25: 2687-2690.

InTERgovernmental OCEANOgRaPhic Commission. Revised Edition (2013). Tsunami Glossary, Paris, UNESCO. IOC Technical Series, 85. (English.) (IOC/2008/TS/85rev).

KANAMORI, H., and Rivera, L. (2008). Source inversion of W phase: speeding up seismic tsunami warning, Geophys. J. Int., 175(1): 222-238.

Lorito, S., Tiberti, M. M., Basili, R., Piatanesi, A., and Valensise, G. (2008). Earthquake generated tsunamis in the Mediterranean Sea: Scenarios of potential threats to Southern Italy, J. Geophys. Res., 113, B01301.

Pondrelli, S., Morelli, A., and Exstrom, G. (2004). EuropeanMediterranean regional centroid-moment tensor catalog: solutions for years 2001 and 2002, Phys. Earth Planet. Int., 145: 127-147.

Reymond, D. and Clément J. (2014). New Tsunami Forecast Tools for the French Polynesia Warning System: Part I: moment tensor, slowness and seismic source inversion, Pure and Applied Geophysics, this issue.

Roger, J. and HéBert, H. (2008). The 1856 Djidjelli (Algeria) earthquake and tsunami: source parameters and implications for tsunami hazard in the Balearic Islands, Natural Hazards and Earth System Sciences, 8: 721-731.

Roger, J., Hébert, H., Ruegg, J.-C., and Briole, P. (2011). The El Asnam 1980 October 10 inland earthquake: a new hypothesis of tsunami generation, Geophys. J. Int, 185, 1135-1146.

Roudil, P., Schindelé, F., Bossu, R., Alabrune, N., Arnoul, P., Duperray, P., Gailler, A., Gullbert, J., Hébert, H. LoevenBRUCK, A. (2013). French tsunami warning center for the Mediterranean and the northeast Atlantic-CENALT, Science of tsunami hazard, 32(1): 1-7.

Sahal, A., Roger, J., Allgeyer, S., Lemaire, B., Hébert, H., Schindelé, F., and Lavigne, F. (2009). The tsunami triggered by the 21 May 2003 Boumerdès-Zemmouri (Algeria) earthquake: field investigations on the French Mediterranean coast and tsunami modelling, Nat. Hazards Earth Syst. Sci., 9: 1823-1834.

Schindelé, F., Loevenbruck, A., Hébert, H. (2008). Strategy to design the sea-level monitoring networks for small tsunamigenic 
oceanic basins: the Western Mediterranean case, Nat. Hazards Earth Syst. Sci., 8: 1019-1027.

Shokin, Y., Chubarov, L. B., Novikov, V. A., Subabov, A. N. (1987). Calculations of tsunami travel times charts in the Pacific Ocean (models, algorithms, techniques, results), Science of tsunami hazards, 5: 85-114.

Sorensen, M. B., Spada, M., Babeyko, A., Wiemer, S., and Grunthal, G. (2012). Probabilistic tsunami hazard in the Mediterranean Sea, J. Geophys. Res., 117, B01305.

UNESCO (2012), Interim Operational Users Guide for the Tsunami Early Warning and Mitigation System in the North-eastern
Atlantic, the Mediterranean and Connected Seas (NEAMTWS) Version 2.00. (http://ioc-unesco.org/index.php?option=com oe\&task=viewDocumentRecord\&docID=12077).

Wells, D. L. and Coppersmith, K. J.(1994). New empirical relationships among magnitude, rupture length, rupture width, rupture area, and surface displacement, Bull. Seismol. Soc. Am., 84: 974-1002. Yelles-Chaouche, A., Roger, J., Déverchère, J., Bracène, R., Domzig, A., Hébert, H. and Kherroubi, A.(2009). The 1856 Tsunami of Djidjelli (Eastern Algeria): Seismotectonics, Modelling and Hazard Implications for the Algerian Coast, Pure and Applied Geophysics, 166: 283-300.

(Received May 6, 2014, revised September 25, 2014, accepted September 30, 2014, Published online December 2, 2014) 